\title{
PENYELESAIAN SENGKETA DALAM HUKUM EKONOMI ISLAM
}

\section{Nurhayati}

Sekolah Tinggi Agama Islam DDI Maros || email: nurhayatijallo@yahoo.co.id

\begin{abstract}
Abstrak
Penelitian ini membahas tentang hukum Islam ekonomi yang mana sekarang ini pertumbuhan ekonomi sudah sangat berkembang sesuai dengan era sekarang ini, sehingga masyarakat pun merasa kesulitan dalam penyelesaian permasalahan antara ekonomi Islam klasik dengan ekonomi konvensional. Dalam penulisan ini penulis membatasi dua pokok masalah pertama: Bagaimanakah cara penyelesaian masalah ekonomi tradisi Islam klasik?, dan kedua bagaimana penyelesain ekonomi syariah dalam hukum positif Indonesia?. Tujuan penulisan ini untuk dapat membedakan cara penyelesaian masalah ekonomi dengan menggunkan tradisi klasik dan hukum positif Indonesia. Jenis penelitian yang digunakan adalah library reasearch dengan menggunkan dua pendekatan yaitu pendekatan normatif dan yuridis. Dan hasil penelitian ini ditemukan bahwa (1) Bahwa dalam menyelesaikan permasalah Sengketa Ekonomi Syari'ah Berdasarkan Tradisi Islam Klasik dapat ditempuh dengan cara yaitu Al Sulh (Perdamaian),Tahkim (artbitrase) dan Wilayat al Qadha (Kekuasaan Kehakiman) (2) Penyelesaian Sengketa Ekonomi Syariah Berdasarkan Tradisi Hukum Positif Indonesia dapat di tempuh dengan cara: Perdamaian dan Alternatif Penyelesaian Sengketa (ADR) dan Arbitrase (Tahkim)
\end{abstract}

Kata Kunci: Penyelesaian Sengketa, Hukum Positif 


\begin{abstract}
This study discusses economic Islamic law, which is currently growing economically in accordance with the current era, so that people feel difficulties in solving problems between classical Islamic economics and conventional economics. In this paper the author limits two main problems: How to solve the economic problems of the classical Islamic tradition?, and second, how to solve the Islamic economy in the positive law of Indonesia? The purpose of this paper is to be able to distinguish between ways of solving economic problems by using classical traditions and positive Indonesian law. The type of research used is the reasearch library using two approaches namely normative and juridical approaches. And the results of this study found that (1) that in resolving the problem of Syari'ah Economic Disputes Based on Classical Islamic Traditions can be reached by means of Al Sulh (Peace), Tahkim (artbitrage) and Wilayat al Qadha (Judicial Power) (2) Dispute Settlement Islamic Economics Based on Indonesian Positive Legal Traditions can be taken by: Peace and Alternative Dispute Settlement (ADR) and Arbitration (Tahkim)
\end{abstract}

Keywords: Dispute resolution, Positive law

\section{PENDAHULUAN}

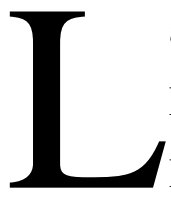

ahirnya

Undang-Undang

Nomor 3 Tahun 2006 tentang

Perubahan Undang-Undang

Nomor 7 Tahun 1989 Tentang Peradilan

Agama telah membawa perubahan

besar dalam eksistensi lembaga

Peradilan Agama saat ini. Salah satu

perubahan

mendasar

adalah

penambahan wewenang lembaga

Peradilan Agama antara lain dalam

bidang ekonomi syariah. Disamping itu,

lahirnya Undang-Undang Nomor 41

Tahun 2004 tentang Wakaf juga telah

memberikan nuansa baru pada lembaga

Peradilan Agama, sebab pengaturan

wakaf dengan undang-undang ini tidak

hanya menyangkut tanah milik, tetapi juga mengatur tentang wakaf produktif yang juga menjadi kewenangan lembaga Peradilan Agama untuk menyelesaikan berbagai sengketa dalam pelaksanaannya. Berdasarkan pasal 49 huruf (i) Undang-Undang Nomor 3 Tahun 2006 tentang Perubahan Undang-Undang Nomor 7 Tahun 1989 Tentang

Peradilan Agama ditegaskan bahwa Peradilan Agama bertugas dan berwenang memeriksa, mengadili dan menyelesaikan perkara termasuk "ekonomi syariah". Yang dimaksud dengan ekonomi syari.ah adalah perbuatan atau kegiatan usaha yang dilaksanakan menurut prinsip syariah yang meliputi bank syari.ah, lembaga 


\section{J-HES}

Jurnal Hukum Ekonomi Syariah

Volume 3, No. 1, Januari-Juni 2019 | p-ISSN: 2549-4872 | e-ISSN: 2654-4970

keuangan mikro syariah, asuransi syariah, asuransi syariah, obligasi syariah dan surat berharga berjangka menengah syariah, pembiayaan syariah, pergadaian syariah, dana pensiun lembaga keuangan syariah dan bisnis syariah. Maka masalah pokok yang menjadi fokus dalam tulisan ini yaitu bagaimanakah cara penyelesaian masalah ekonomi tradisi Islam klasik? bagaimana penyelesaian masalah ekonomi syariah dalam hukum positif Indonesia?

\section{METODE PENELITIAN}

Pada penelitian ini penulis menggunakan metode library research dan Pendekatan yang digunakan dalam penelitian ini menggunakan beberapa pendekatan yaitu:

a. Pendekatan Normatif (pendekatan syar'i). Yaitu pendekatan yang mengakaji nilai-nilai syariat islam sesuai dengan yang berkaitan dengan masalah penelitian dengan cara meneliti bahan pustaka atau data sekunder.

b. Pendekatan Yuridis (legal fomat atau berdasarkan Undang-undang yang berkaitan). Yaitu pendekatan dengan melihat Undang-undang yang sesuai atau data primer yang berkaitan dengan masalah yang diteliti oleh peneliti.

\section{PEMBAHASAN}

\section{A. Penyelesaian Sengketa Ekonomi Syari'ah Berdasarkan Tradisi} Islam Klasik.

1. Al Sulh (Perdamaian)

Secara bahasa, "sulh" berarti meredam pertikaian, sedangkan menurut istilah "sulh" berarti suatu jenis akad atau perjanjian untuk mengakhiri perselisihan/pertengkaran antara dua pihak yang bersengketa secara damai. Menyelesaikan sengketa berdasarkan perdamaian untuk mengakhiri suatu perkara sangat dianjurkan oleh Allah swt sebagaimana tersebut dalam surat An Nisa. ayat 126 yang terjemahnya "Perdamaian itu adalah perbuatan yang baik".Ada tiga rukun yang harus dipenuhi dalam perjanjian perdamaian yang harus dilakukan oleh orang melakukan perdamaian, yakni ijab, qabul dan lafazd dari perjanjian damai tersebut.

Tentang (AW Munawir, Kamus Al Munawir:1984: 843) subyek atau orang yang melakukan perdamaian harus orang cakap bertindak menurut 
hukum. Selain dari itu orang yang melaksanakan perdamaian harus orang yang mempunyai kekuasaan atau mempunyai wewenang untuk melepaskan haknya atau hal-hal yang dimaksudkan dalam perdamaian tersebut. Belum tentu setiap orang yang cakap bertindak mempunyai kekuasaan atau wewenang. Orang yang cakap bertindak menurut hukum tetapi tidak mempunyai wewenang untuk memiliki seperti pertama : wali atas harta benda orang yang berada dibawah perwaliannya, kedua : pengampu atas harta benda orang yang berada di bawah pengampuannya, ketiga : nazir (pengawas) wakaf atas hak milik wakaf yang ada di bawah pengawasannya.

Hal yang menyangkut obyek [Said Agil Husein al Munawar: 1994: 48-49] tentang obyek dari perdamaian harus memenuhi ketentuan yakni pertama : berbentuk harta, baik berwujud maupun yang tidak berwujud seperti hak milik intelektual, yang dapat dinilai atau dihargai, dapat diserahterimakan dan bermanfaat, kedua : dapat diketahui secara jelas sehingga tidak melahirkan kesamaran dan ketidakjelasan, yang pada akhirnya dapat pula melahirkan pertikaian baru terhadap obyek yang sama.

Persoalan yang boleh didamaikan (disulh-kan) para ahli hukum Islam sepakat bahwa hal-hal yang dapat dan boleh didamaikan hanya dalam bentuk pertikaian harta benda yang dapat dinilai dan sebatas hanya kepada hakhak manusia yang dapat diganti. Dengan kata lain, persoalan perdamaian itu hanya diperbolehkan dalam bidang muamalah saja, sedangkan hal-hal yang menyangkal hak-hak Allah tidak dapat didamaikan.

Pelaksana perdamaian, pelaksana perjanjian damai bisa dilaksanakan dengan dua cara, yakni di luar sidang pengadilan atau melalui siding pengadilan. Diluar sidang Pengadilan, penyelesaian sengketa dapat dilaksanakan baik oleh mereka sendiri (yang melakukan perdamaian) tanpa melibatkan pihak lain, atau meminta bantuan orang lain untuk menjadi penengah (wasit), itulah yang kemudian disebut dengan arbitrase, atau dalam syari.at Islam disebut dengan hakam. Pelaksanaan perjanjian damai melalui sidang Pengadilan dilangsungkan pada saat perkara sedang diproses dalam siding Pengadilan. Di dalam ketentuan 


\section{J-HES}

Jurnal Hukum Ekonomi Syariah

Volume 3, No. 1, Januari-Juni 2019 | p-ISSN: 2549-4872 | e-ISSN: 2654-4970

perundang-undangan ditentukan bahwa sebelum perkara diproses, atau dapat juga selama diproses bahkan sudah diputus oleh Pengadilan tetapi belum mempunyai kekuatan hukum tetap, hakim harus menganjurkan agar para pihak yang bersengketa supaya berdamai. Seandainya hakim berhasil mendamaikan pihak-pihak yang bersengketa, maka dibuatlah putusan perdamaian, kedua belah pihak yang melakukan perdamaian itu dihukum untuk mematuhi perdamaian yang telahmereka sepakati. Perjanjian perdamaian (sulh) yang dilaksanakan sendiri oleh kedua belah pihak yang berselisih atau bersengketa, dalam praktek dibeberapa negara Islam, terutama dalam hal perBankkan Syariah disebut dengan "tafawud" dan "taufiq" (perundingan dan penyesuaian). Kedua hal yang terakhir ini biasanya dipakai dalam mengatasi persengketaan antara intern Bank, khususnya Bank dan lembaga-lembaga keuangan pemerintah.

\section{Tahkim (Arbitrase)}

Dalam perspektif Islam, "arbitrase" dapat dipadankan dengan istilah "tahkim". Tahkim sendiri berasal dari kata "hakkama". Secara etimologi, tahkim berarti menjadikan seseorang sebagai pencegah suatu sengketa. Secara umum, tahkim memiliki pengertian yang sama dengan arbitrase yang dikenal dewasa ini yakni pengangkatan seseorang atau lebih sebagai wasit oleh dua orang yang berselisih atau lebih, guna menyelesaikan perselisihan mereka secara damai, orang yang menyelesaikan disebut dengan "Hakam".

3. Wilayat al Qadha (Kekuasaan Kehakiman)

Al Hisbah adalah lembaga resmi negara yang diberi wewenang untuk menyelesaikan masalah-masalah atau pelanggaran ringan yang menurut sifatnya tidak memerlukan proses peradilan untuk menyelesaikannya. Menurut Al Mawardi8Kewenangan lembaga Hisbah ini tertuju kepada tiga hal yakni pertama : dakwaan yang terkait dengan kecurangan dan pengurangan takaran atau timbangan, kedua : dakwaan yang terkait dengan penipuan dalam komoditi dan harga seperti pengurangan takaran dan timbangan di pasar, menjual bahan makanan yang sudah kadaluarsa dan ketiga : dakwaan yang terkait 
dengan penundaan pembayaran hutang padahal pihak yang berhutang mampu membayarnya. Dari uraian tersebut di atas dapat diketahui bahwa kekuasaan al Hisbah ini hanya terbatas pada pengawasan terhadap penunaian kebaikan dan melarang orang dari kemunkaran.

Kemudian Al Madzalim, Badan ini dibentuk oleh pemerintah untuk membela orangorang teraniaya akibat sikap semena-mena dari pembesar Negara atau keluarganya, yang biasanya sulit untuk diselesaikan oleh Pengadilan biasa dan kekuasaan hisbah. Kewenangan yang dimiliki oleh lembaga ini adalah menyelesaikan kasus-kasus pelanggaran hukum yang dilakukan oleh aparat atau pejabat pemerintah seperti sogok menyogok, tindakan korupsi dan kebijakan pemerintah yang merugikan masyarakat. Orang yang berwenang menyelesaikan perkara ini disebut dengan nama wali al Mudzalim atau al Nadlir.

Al Qadha (Peradilan) menurut arti bahasa, al Qadha berarti memutuskan atau menetapkan. Menurut istilah berarti "menetapkan hukum syara.pada suatu peristiwa atau sengketa untuk menyelesaikannya secara adil dan mengikat". Adapun kewenangan yang dimiliki oleh lembaga ini adalah menyelesaikan perkara-perkara tertentu yang berhubungan dengan masalah al ahwal asy syakhsiyah (masalah keperdataan, termasuk didalamnya hukum keluarga), dan masalah jinayat (yakni hal-hal yang menyangkut pidana).Orang yang diberi wewenang menyelesaikan perkara di Pengadilan disebut dengan qadhi (hakim).

\section{B. Penyelesaian Sengketa Ekonomi Syariah Berdasarkan Tradisi Hukum Positif Indonesia}

1. Perdamaian dan Alternatif Penyelesaian Sengketa $(A D R)$

(Wahbah Az Zuhaili, 2005:752) Konsep sulh (perdamaian) sebagaimana yang tersebut dalam berbagai kitab fiqih merupakan satu dokrin utama hukum Islam dalam bidang muamalah untuk menyelesaikan suatu sengketa, dan ini sudah merupakan conditio sine quo non dalam kehidupan masyarakat manapun, karena pada hakekatnya perdamaian bukalah suatu pranata positif belaka, melainkan lebih berupa fitrah dari manusia. Segenap manusia menginginkan 


\section{J-HES}

Jurnal Hukum Ekonomi Syariah

Volume 3, No. 1, Januari-Juni 2019 | p-ISSN: 2549-4872 | e-ISSN: 2654-4970

seluruh aspek kehidupannya nyaman, tidak ada yang mengganggu, tidak ingin dimusuhi, ingin damai dan tenteram dalam segala aspek kehidupan. Dengan demikian institusi perdamaian adalah bagian dari kehidupan manusia. Pemikiran kebutuhan akan lembaga sulh (perdamaian) pada zaman modern ini tentunya bukanlah suatu wacana dan cita-cita yang masih utopis, melainkan sudah masuk ke wilayah praktis.

Hal ini dapat dilihat dengan marak dan populernya Alternative Dispute Resolution (ADR). Untuk kontek Indonesia, perdamaian telah didukung keberadaannya dalam hukum positif yakni Undang-Undang Nomor 30 Tahun 1999 Tentang Arbitrase dan Alternatif Penyelesaian Sengketa. Dengan adanya pengaturan secara positif mengenai perdamaian, maka segala hal yang berkaitan dengan perdamaian baik yang masih dalam bentuk upaya, proses tehnis pelaksanaan hingga pelaksanaan putusan dengan sendirinya telah sepenuhnya didukung oleh negara.

Undang-Undang Nomor 30 Tahun 1999 tentang Arbitrase dan Alternatif Penyelesaian Sengketa dapat dikatakan sebagai wujud yang paling riel dan lebih spesifik dalam upaya negara mengaplisikan dan mensosialisasikan institusi perdamaian dalam sengketa bisnis. Dalam undangundang ini pula dikemukakan bahwa negara memberi kebebasan kepada masyarakat untuk menyelesaikan masalah sengketa bisnisnya di luar Pengadilan, baik melalui konsultasi, mediasi, negosiasi, konsiliasi atau penilaian para ahli.

Menurut Suyud Margono kecenderungan memilih Alternatif Dispute Resolution (ADR) oleh masyarakat dewasa ini didasarkan atas pertimbangan pertama : kurang percaya pada sistem pengadilan dan pada saat yang sama sudah dipahaminya keuntungan mempergunakan sistem arbitrase dibanding dengan Pengadilan, sehingga masyarakat pelaku bisnis lebih suka mencari alternatif lain dalam upaya menyelesaikan berbagai sengketa bisnisnya yakni dengan jalan Arbitrase, kedua: kepercayaan masyarakat terhadap lembaga arbitrase khususnya BANI mulai menurun yang disebabkan banyaknya klausul-klausul arbitrase yang tidak berdiri sendiri sendiri, melainkan mengikuti dengan klausul kemungkinan pengajuan 
sengketa ke Pengadilan jika putusan arbitrasenya tidak berhasil diselesaikan.

Dengan kata lain, tidak sedikit kasus-kasus sengketa yang diterima oleh Pengadilan merupakan kasuskasus yang sudah diputus oleh arbitrase BANI. Dengan demikian penyelesaian sengketa dengan cara ADR merupakan alternatif yang menguntungkan. Undang-Undang Nomor 30 Tahun 1999 Tentang Arbitrase dan Alternatif Penyelesaian Perkara mengatur tentang penyelesaian

Sengketa di luar Pengadilan, yakni melalui konsultasi, mediasi, negosiasi, konsiliasi dan penilaian ahli. Undang-Undang ini tidak seluruhnya memberikan pengertian atau batasanbatasan secara rinci dan jelas. Disini akan dijelaskan tentang pengertian singkat tentang bentuk-bentuk ADR sebagai berikut :

a. Konsultasi

Black.s Law Dictionary memberi pengertian Konsultasi adalah "aktivitas konsultasi atau perundingan seperti klien dengan penasehat hukumnya"

b. Negosiasi

Negosiasi adalah proses yang dilakukan oleh dua pihak dengan permintaan (kepentingan) yang saling berbeda dengan membuat suatu persetujuan secara kompromis dan memberikan kelonggaran.

c. Konsiliasi

Konsiliasi adalah penciptaan penyesuaian pendapat dan penyelesaian suatu sengketa dengan suasana persahabatan dan tanpa ada rasa permusuhan yang dilakukan di pengadilan sebelum dimulainya persidangan dengan maksud untuk menghindari proses legitasi.

d. Pendapat atau Penilaian Ahli (Muhammad Ibnu Farhum: 1031:19) Bentuk ADR lainnya yang diintrodusir dalam Undang-Undang Nomor 30 Tahun 1990 adalah pendapat (penilaian) ahli. Dalam rumusan pasal 52 Undang-Undang ini dinyatakan bahwa para pihak dalam suatu perjanjian berhak untuk memohon pendapat yang mengikat dari lembaga arbitrase atas hubungan hukum tertentu dari suatu perjanjian.

\section{Arbitrase (Tahkim)}

Biasanya dalam kontrak bisnis sudah disepakati dalam kontrak yang dibuatnya untuk menyelesaikan sengketa yang terjadi dikemudian hari di antara mereka. Usaha penyelesaian 


\section{J-HES}

Jurnal Hukum Ekonomi Syariah

Volume 3, No. 1, Januari-Juni 2019 | p-ISSN: 2549-4872 | e-ISSN: 2654-4970

sengketa dapat diserahkan kepada forum-forum tertentu sesuai dengan kesepakatan.

Di Indonesia terdapat beberapa lembaga arbitrase untuk menyelesaikan berbagai sengketa bisnis yang terjadi dalam lalu lintas perdagangan, antara lain BAMUI (Badan Arbitrase Muamalat Indonesia) yang khusus menangani masalah persengketaan dalam bisnis Islam, BASYARNAS (Badan Arbitrase Syari.ah Nasional) yang menangani masalah-masalah yang terjadi dalam pelaksanaan Bank Syari.ah, dan BANI (Badan Arbitrase Nasional Indonesia) yang khusus menyelesaikan sengketa bisnis non Islam.

a. Badan Arbitrase Nasional Indonesia $(B A N I)$

Sebagian besar di negara-negara barat telah memiliki lembaga arbitrase dalam menyelesaikan berbagai sengketa ekonomi yang timbul akibat wanprestasi terhadap kontrak-kontrak yang dilaksanakannya. Dalam kaitan ini, Indonesia yang merupakan bagian dari masyarakat dunia juga telah memiliki lembaga arbitrase dengan nama Badan Arbitrase Nasional Indonesia yang disingkat dengan BANI.
Adapun tujuan didirikannya Badan Arbitrase Nasional Indonesia (BANI) adalah memberikan penyelesaian yang adil dan cepat dalam sengketa-sengketa perdata yang timbul dan berkaitan dengan perdagangan dan keuangan, baik yang bersifat nasional maupun yang bersifat internasional. Di samping itu, keberadaan BANI di samping berfungsi menyelesaikan sengketa, ia juga dapat menerima permintaan yang diajukan oleh para pihak dalam suatu perjanjian untuk memberikan suatu pendapat (legal opinion) yang mengikat mengenai suatu persoalan.

\section{b. Badan Arbitrase Muamalat Indonesia (BAMUI)}

Perkembangan bisnis ummat Islam berdasar syari.ah semakin menunjukkan kemajuannya, maka kebutuhan akan lembaga yang dapat menyelesaikan persengketaan yang terjadi atau mungkin terjadi dengan perdamaian dan prosesnya secara cepat merupakan suatu kebutuhan yang sangat mendesak.

Adapun tujuan dibentuk BAMUI adalah pertama: memberikan penyelesaian yang adil dan cepat dalam sengketa-sengketa muamalah perdata 
yang timbul dalambidang perdagangan, industri, keuangan, jasa dan lainlain, kedua : menerima permintaan yang diajukan oleh para pihak dalam suatu perjanjian tanpa adanya suatu sengketa untuk memberikan suatu pendapat yang mengikat mengenai suatu persoalan berkenaan dengan perjanjian tersebut. (Suyud Margono, 2000: 82)

c. Badan Arbitrase Syariah Nasional (BASYARNAS)

Badan Arbitrase Syariah Nasional (BASYARNAS) berkedudukan di Jakarta dengan cabang atau perwakilan di tempattempat lain yang dipandang perlu. Badan Arbitrase Syariah Nasional (BASYARNAS) sesuai dengan Pedoman Dasar yang di tetapkan oleh MUI : ialah lembaga hakam yang bebas, otonom dan independent, tidak boleh dicampuri oleh kekuasaan dan pihak-pihak manapun. Badan Arbitrase Syariah Nasional (BASYARNAS) adalah perangkat organisasi.

\section{KESIMPULAN}

Berdasaarkan pembahsan pada bab sebelumnya, maka penulis dapa menarik kesimpulan dari tulisan ini yakni:

1. Bahwa dalam menyelesaikan permasalah Sengketa Ekonomi Syari'ah Berdasarkan Tradisi Islam Klasik dapat ditempuh dengan cara di bawah ini:

\section{a. Al Sulh (Perdamaian)}

Secara bahasa, "sulh" berarti meredam pertikaian, sedangkan menurut istilah "sulh" berarti suatu jenis akad atau perjanjian untuk mengakhiri perselisihan/ pertengkaran antara dua pihak yang bersengketa secara damai.

b. Tahkim (artbitrase) berarti menjadikan seseorang sebagai pencegah suatu sengketa

c. Wilayat al Qadha (Kekuasaan Kehakiman)

2. Penyelesaian Sengketa Ekonomi Syariah Berdasarkan Tradisi Hukum Positif Indonesia dapat di tempuh dengan cara dibawah ini:

a. Perdamaian dan Alternatif Penyelesaian Sengketa $(A D R)$

b. Arbitrase (Tahkim) 


\section{J-HES}

Jurnal Hukum Ekonomi Syariah

Volume 3, No. 1, Januari-Juni 2019 | p-ISSN: 2549-4872 | e-ISSN: 2654-4970

\section{DAFTAR PUSTAKA}

Harahap, M. Yahya. 1989. Kedudukan Kewenangan dalam Acara Peradilan Agama UU No.7 Tahun 1989. Jakarta: Sinar Grafika.

Lubis, Suhrawardi K. 1999. Hukum Ekonomi Islam. Jakarta: Sinar grafika.

Margono, Suyud. 2000. ADR dan Arbitrase Proses Pelembagaan dan Aspek Hukum. Jakarta: Ghalia Indonesia.

Mudzakkir AS. 1989. Ekonomi Islam Masa Kini. Bandung: Husaini.

Muhaemin. 2006. "Kesiapan Pengadilan Agama Tangani Sengketa Ekonomi Syari'ah", Dalam Republika On Line, diakses tgl 4 Desember 2009.

Muhammad Ibnu Farhum. 1031. Tabsirah al Hukkam fi Ushul al Qhadhiyah wa Manahij al Ahkam. Darr al Maktabah al Ilmiah. Jilid I. Libanon: Bairut.

Al-Munawar, Said Agil Husin, Haji. 2003. Fikih Hubungan Antara Agamal Al Munawar, Haji Said Agil Husin/ Abdul Halim Ramli A. Wahab, Irfansyah (Peny.). Jakarta: Ciputat Press.

Munawir, A.W. 1984. Kamus Arab-Indonesia al-Munawir. Yogyakarta: Pon-Pes al-Munawir.

Undang-Undang Ekonomi Syari’ah. 2009. Bandung: Fokus Media.

Zuhaily, Wahbah al. 2006. al-Fiqhul Islamy Wa Adillatuhu. Terjemahan, Bandung: C.V. Pustaka Media Utama. 